\title{
DGKH Gene
}

National Cancer Institute

\section{Source}

National Cancer Institute. DGKH Gene. NCI Thesaurus. Code C119658.

This gene plays a role in both diacylglycerol phosphorylation and the promotion of cell growth. 